\title{
UJI AKTIVITAS ANTIBAKTERI ISOLAT AKTINOMISETES ASAL TANAH HUTAN LARANGAN ADAT GHIMBO POTAI, KABUPATEN KAMPAR, PROVINSI RIAU, TERHADAP Escherichia coli DAN Staphylococcus aureus
}

\author{
Elsie, M.Si ${ }^{1}$, Nur'Atika, S.Si $^{1}$, dan Israwati Harahap, ${ }^{\text {M.Si }}{ }^{1}$ \\ ${ }^{1}$ Program Studi Biologi, Fakultas Matematika, Ilmu Pengetahuan Alam, dan Kesehatan, \\ Universitas Muhammadiyah Riau, Pekanbaru (2829), Riau, Indonesia \\ Email:elsie@umri.ac.id
}

\begin{abstract}
Abstrak
Tujuan penelitian ini untuk menguji aktivitas antibakteri isolat aktinomisetes yang telah diisolasi dari tanah Hutan Larangan Adat Ghimbo Potai, Kabupaten Kampar, Provinsi Riau. Penelitian dilakukan pada bulan April sampai dengan Juli tahun 2016. Uji aktivitas dilakukan menggunakan metode difusi agar terhadap 2 bakteri uji yaitu Escherichia coli and Staphylococcus aureus. Hasil uji aktivitas isolat aktinomisetes NA-1 dan NA-2 menunjukkan bahwa hanya isolat NA-1 yang memiliki kemampuan menghambat pertumbuhan bakteri $S$. aureus dengan diameter zona penghambatan sebesar $7 \mathrm{~mm}$.
\end{abstract}

Keywords: Actinomycetes, Antibacterial, Escherichia coli, Staphylococcus aureus.

\section{PENDAHULUAN}

Tingginya angka kesakitan (morbidity) dan kematian (mortality) di negara berkembang disebabkan oleh penyakit infeksi. Mikroba penyebab penyakit infeksi diantaranya adalah virus, jamur, dan bakteri (Darmadi, 2008). Bakteri telah ditemukan sebagai organisme di bumi sejak triliunan tahun yang lalu. Untuk dapat bertahan hidup, bakteri mengembangkan mekanisme resistensi terhadap antibiotik. Tidak mengherankan bila sampai saat ini beberapa bakteri menjadi resisten terhadap agen antimikroba alami yang telah dikembangkan sejak beberapa puluh tahun yang lalu. S. aureus misalnya, resisten terhadap metisilin, merupakan bakteri penyebab beberapa penyakit infeksi setiap tahunnya (Demain \& Sanchez, 2009). Beberapa kelompok bakteri Gram positif (Enterococcus dan Streptococcus) dan Gram negatif (Enterobacter, Eschericia,
Serratia, Klebsiella, Pseudomonas dan Salmonella) menjadi penyebab infeksi nosokomial (Cragg \& Newman, 2001). Untuk itu diperlukan antibiotik-antibiotik baru untuk dapat melawan secara aktif bakteri patogen yang telah resisten.

Diantara mikroorganisme yang memiliki nilai penting di dalam industri, aktinomisetes merupakan produsen utama antibiotik dan beberapa senyawa metabolit sekunder. Populasi aktinomisetes menjadi bagian penyusun organisme tanah, dari berbagai jenis tanah. Mikroba ini banyak di dalam tanah, di laut, di ekosistem darat, dan bersimbiosis dengan tanaman atau organisme lainnya. Selain sebagai penghasil antibiotik dan senyawa metabolit sekunder, aktinomisetes juga merupakan produsen enzim selulase, silanase, pektinase, amilase, lipase, dan protease. Lebih lanjut, aktinomisetes juga menghasilkan siderofor yang dapat diaplikasikan di bidang medis dan 
pertanian. Senyawa bioaktif yang dihasilkan oleh aktinomisetes memiliki peran sebagai senyawa antimikroba, antitumor, antiinflamasi, dan antivirus (Rana \& Salam, 2014).

Beberapa penelitian telah dilakukan dalam mengeksplorasi potensi aktinomisetes diantaranya dari hasil penelitian Rana \& Salam (2014), dari 23 isolat aktinomisetes yang diuji 7 diantaranya memberikan penghambatan yang signifikan terhadap bakteri Gram positif ( $S$. aureus) dan Gram negatif (Klebsiella pneumonia, Salmonella enterica typhimurium, dan E. coli), serta kelompok cendawan (Trichodermaviridae dan Altenaria alternata). Sunaryanto et. al. (2010) telah berhasil mendapatkan 29 isolat aktinomisetes yang diisolasi dari berbagai sampel sedimen dan setelah dilakukan uji terhadap E. coli ATCC 25922, S. aureus ATCC 25923, $P$. aeruginosa ATCC 27853, Bacillus subtilis ATCC 66923, Candida albicans BIOMCC 0122, dan Aspergillus niger BIOMCC 0134. Penelitian ini bertujuan untuk menguji aktivitas antibakteri 2 isolat aktinomisetes (NA-1 dan NA-2) yang telah diisolasi dari tanah Hutan Larangan Adat Ghimbo Potai, Kabupaten Kampar, Provinsi Riau, terhadap bakteri uji E. coli dan S. aureus.

\section{METODE PENELITIAN}

\section{Sampel Isolat Aktinomisetes dan}

Bakteri Uji.

Isolat aktinomisetes yang digunakan yaitu NA-1 dan NA-2 telah disolasi sebelumnya dari tanah Hutan Larangan Adat Ghimbo Potai, Kabupaten Kampar, Provinsi Riau sedangkan bakteri uji yang digunakan adalah E. coli dan $S$. aureus. Penelitian ini dilakukan dari Bulan April sampai dengan Bulan Juli 2016 dan sampel diuji di Laboratorium Biologi, Fakultas MIPA dan Kesehatan, Universitas Muhammadiyah Riau.

\section{Peremajaan dan Produksi Senyawa Antibakteri Isolat Aktinomisetes}

Isolat aktinomisetes diinokulasikan pada media Starch Casein Agar (SCA) yang telah ditambahkan $0.05 \mathrm{mg} / \mathrm{ml}$ nistatin sebagai antifungi dengan metode cawan gores, kemudian diinkubasi selama selama $7-14$ hari pada suhu $28{ }^{\circ} \mathrm{C}$. Produksi senyawa antibakteri dilakukan dengan cara menginokulasikan isolat pada media Starch Casein Broth $9 \mathrm{~mL}$ menggunakan ose dan diinkubasikan pada suhu $30{ }^{\circ} \mathrm{C}$ selama 7 - 14 hari.

\section{Uji Aktivitas Senyawa Antibakteri Isolat Aktinomisetes}

Uji aktivitas senyawa antibakteri isolat aktinomisetes terhadap bakteri uji ( $E$. coli dan $S$. aureus) dilakukan dengan metode difusi. Kekeruhan suspensi bakteri uji disamakan dengan kekeruhan standar Mc. Farland dan diseka ke media NA sampai merata di permukaan media NA. Setelah media mengering, kertas saring steril yang berdiameter $8 \mathrm{~mm}$ yang telah dicelupkan ke dalam filtrat isolat aktinomisetes diletakkan di atas media NA yang telah diinokulasikan bakteri uji, selanjutnya diinkubasi pada suhu $30{ }^{\circ} \mathrm{C}$ selama 24 jam. Pengamatan terhadap zona hambat (zona bening) yang terbentuk dilakukan dengan cara mengukur diameter zona bening dikurangi dengan diameter kertas saring (Willey et al., 2008). Bila diameter daerah hambatan sebesar 5 - 14 mm maka aktivitas penghambatannya dikategorikan lemah, diameter 15 - $24 \mathrm{~mm}$ dikategorikan sedang dan bila lebih dari atau sama dengan $25 \mathrm{~mm}$ dikategorikan aktivitas daya hambatnya kuat (Nedialkova 


\section{Analisis Data}

Data hasil pengukuran zona bening yang terbentuk dianalisis secara deskriptif untuk menentukan penghambatan yang diberikan oleh kedua isolat aktinomisetes

\section{HASIL DAN PEMBAHASAN}

Hasil uji aktivitas antibakteri isolat aktinomisetes (NA-1 dan NA-2) terhadap bakteri E. coli dan S.aureus dapat dilihat pada Tabel 1 berikut.

Tabel 1. Hasil Uji Aktivitas Antibakteri Isolat NA-1 dan NA-2

\begin{tabular}{cccccc}
\hline No. & Kode isolat & Bakteri uji & Zona bening & Diameter & Kriteria \\
\hline 1. & NA-1 & E. coli & Tidak ada & - & - \\
& & S. aureus & Ada & $7 \mathrm{~mm}$ & Lemah \\
2. & NA-2 coli & S. areus & Tidak ada & - & - \\
& & & Tidak ada & - & -
\end{tabular}

Hasil uji aktivitas antibakteri kedua isolat aktinomisetes (lihat Tabel 1) menunjukkan bahwa hanya isolat NA-1 yang mampu menghambat bakteri uji $S$. aureus. Hal ini mengindikasikan bahwa isolat NA-1 memiliki potensi sebagai penghasil senyawa antibakteri untuk menghambat salah satu bakteri Gram positif dengan cara mensekresikan senyawa tersebut ke media (lihat Gambar 1). Susilowati et al. (2007) melaporkan bahwa dari 19 isolat yang digunakan, dua diantaranya memberikan penghambatan terbaik dengan zona hambat 11 dan 11,5 $\mathrm{mm}$. Penghambatan terhadap bakteri uji yang digunakan (Eschericia coli K1.1. dan Pseudomonas pseuodomallei 02 05) yang digunakan diduga karena adanya senyawa antibakteri yang disekresikan ke media. Semakin banyak senyawa antibakteri yang disekresikan ke media maka semakin besar zona hambat yang terbentuk.

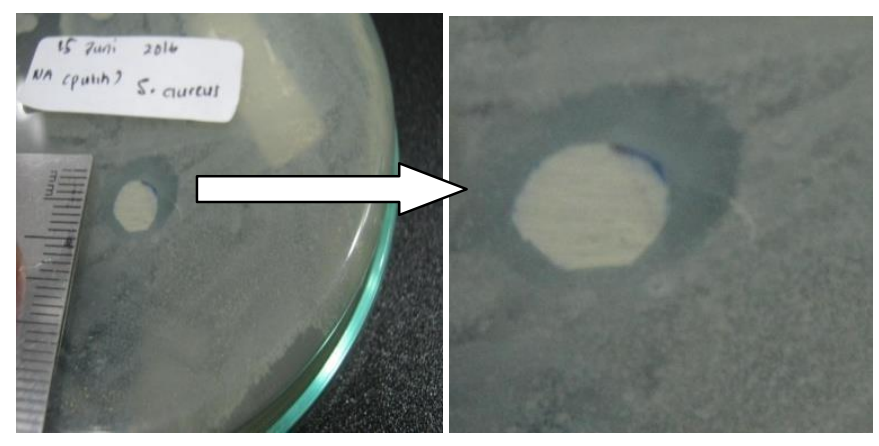

Gambar 1. Hasil uji aktivitas antibakteri isolat NA-1 terhadap S. aureus pada media Nutrient Agar (NA)

Baik isolat NA-1 maupun NA-2 tidak ada yang mampu memberikan penghambatan terhadap pertumbuhan $E$. coli sebagai bakteri uji. Hal ini dapat terjadi kemungkinan karena senyawa antibakteri yang disekresikan oleh kedua isolat aktinomisetes tersebut jumlahnya masih sedikit atau kemungkinan isolat tersebut memiliki potensi lain yang tidak hanya menghasilkan senyawa antibakteri. 
Menurut Deepa et al. (2013), Actinomycetes menghasilkan senyawa bioaktif berupa metabolit sekunder seperti antibiotika dan agen antitumor. Metabolit tersebut diketahui memiliki aktivitas sebagai antibakteri, antifungi, antioksidan, neuritogenik, antikanker, anti malaria dan anti inflamasi. Ambarwati dan Azizah (2009) dalam penelitiannya juga berhasil mengisolasi 11 isolat aktinomisetes dari tanah sawah dan tiga isolat diantaranya mampu menghambat pertumbuhan $S$. aureus ATCC 25923, yaitu isolat SS13 dengan diameter daerah hambatan sebesar $14,66 \mathrm{~mm}$ (sedang), isolat SR1 $=24,66 \mathrm{~mm}$ (kuat) dan isolat SR6 $=5,00 \mathrm{~mm}$ (lemah). Namun demikian tidak ada satupun isolat yang mampu menghambat E. coli ATCC 35218.

Pada Gambar 1 terlihat zona bening yang terbentuk dari hasil uji isolat NA-1 terhadap $S$. aureus sebesar $7 \mathrm{~mm}$. Besarnya penghambatan tersebut dikategorikan lemah. Menurut Nedialkova \& Naidenova (2005), jika diameter daerah hambatan sebesar 5 - 14 $\mathrm{mm}$ maka aktivitas penghambatannya dikategorikan lemah, diameter 15 - $24 \mathrm{~mm}$ dikategorikan sedang dan lebih dari atau sama dengan $25 \mathrm{~mm}$ dikategorikan aktivitas daya hambatnya kuat.

\section{KESIMPULAN DAN SARAN}

Isolat aktinomisetes NA-1 yang telah diisolasi dari sampel tanah Hutan Larangan Adat Ghimbo Potai, Kabupaten Kampar, Provinsi Riau, mampu menghambat pertumbuhan $S$. aureus dengan zona hambatan sebesar $7 \mathrm{~mm}$ (kategori penghambatan lemah). Sementara kedua isolat tersebut tidak ada yang mampu menghambat pertumbuhan $E$. coli. Perlu dilakukan penelitian lanjutan untuk menguji aktivitas kedua isolat tersebut sebagai senyawa antifungi dan karakterisasi kondisi optimum (temperature, $\mathrm{pH}$, dan media pertumbuhan) untuk produksi isolat aktinomisetes.

\section{DAFTAR PUSTAKA}

Cragg, G.M. and D. J. Newman. Medicinals for The Millennia. The Historic Record. Ann NY Acad. Sci. (2001) 953a, 3 - 25 .

Darmadi, 2008. Infeksi Nosokomial

Problematika dan Pengendaliannya, 5, Jakarta, Salemba Medika.

Deepa, S., K. Kanimozhi, and A. Panneerselvam. 2013. 16S rDNA

Phylogenetic Analysis of

Actinomycetes Isolated from Marine

Environment Associated with Antimicrobial Activities.

Hygeia.J.D. Med. 5 (2) October 2013, 43-50.

Demain, A.L. and S. Sanchez. Microbial Drug Discovery: 80 Years of

Progress. The Journal of Antibiotics (2009) 62: 5 - 16.

Nedialkova, D. \& M. Naidenova. 2005. Screening the Antimicrobial Activity of Actinomycetes Strains Isolated from Antarctica, Journal of Culture Collections, 4, 29-35.

Rana, S. and M.D. Salam. Antimicrobial

Potential of Actinomycetes Isolated from Soil Samples of Punjab, India. Journal of Microbiology \& Experimentation. (2014) Vol 1, issue 2.

Sunaryanto, R., B. Marwoto, T.T. Irawadi, Z.A. Mas'ud, and L. Hartoto. 2010. Isolation and Characterization of Antimicrobial Substance from Marine Streptomyces sp. Jurnal Mikrobiologi Indonesia Vol 4 (2): 84 $-89$.

Susilowati, D. N., R.D. Hastuti, dan E. 
Yuniarti. 2007. Isolasi dan Karakterisasi Aktinomisetes Penghasil Antibakteri Enteropatogen Eschericia coli K1.1, Pseudomonas pseuodomallei 02 05, dan Listeria monocytogenes $5407 . \quad$ Jurnal
AgroBiogen 3(1): 15 - 23.

Willey, J.M., L.M. Sherwood, and C.J. Woolverton. 2008. Prescott, Haley, and Klein's Microbiology. 7ed. McGraw Hill, Boston. 